\title{
Shoreline response of eroding soft cliffs due to hard defences
}

Sally Brown MRes, PhD

Research Fellow, Faculty of Engineering and the Environment, University of Southampton, Southampton, UK

Max E. Barton MSC, PhD, DIC, CGeol, CSCi

Emeritus Senior Lecturer, Faculty of Engineering and the Environment,

University of Southampton, Southampton, UK

\section{Robert J. Nicholls PhD}

Professor of Coastal Engineering, Faculty of Engineering and the Environment, University of Southampton, Southampton, UK

Soft cliff retreat has often triggered a hard adaptation response by the building of seawalls and groynes. On adjacent undefended coasts erosion continues, resulting in set-backs. This paper examines the impact of coastal defences on the adjacent coast from historic records and present practices, and explores possible future response. Continued setback often leads to outflanking of defences, making them ineffective at their extremities, particularly at the downdrift end where it is most severe. Solutions to outflanking usually involve extending defences, initiating a cycle of set-back, outflanking and further extensions. Multiple defence extensions and continued retreat of the unprotected adjacent coast results in artificial headland formation. Over several decades, headlands experience foreshore steepening and reduced sediment availability, making them more difficult and expensive to defend. Shoreline management plan policies of managed retreat advocate selective defence abandonment, which may change the nature of artificial headland formation. Defence abandonment and new engineering works must be planned, anticipating the processes described in this paper. This will reduce unexpected changes and reduce maintenance and emergency work costs.

\section{Introduction}

Soft cliff coasts (those formed of clays, shales, sandstones or unconsolidated sands; Jones and Lee (1994); Lee and Clark (2002)) have been eroding for centuries. Particularly since the mid-nineteenth century, adapting to coastal change through the building of hard defences, such as groynes and seawalls, in response to population growth, tourism and industry, has resulted in large parts of the shoreline being protected. In the UK there is a high reliance on engineered systems to reduce flood and erosional risk: $13 \cdot 7 \%$ of the cliffed and low-lying coast is protected - nearly twice the amount of the European average (Eurosion, 2004).

Although defence schemes have been effective in reducing erosion, the unprotected cliffed coast adjacent to protection schemes continues to erode. Frequently the down-drift coast is more severely affected than the up-drift coast as defences alter the sediment budget, often causing a deficit, resulting in higher rates of land loss than before defence construction. Over time, defences protrude seawards forming a subtle promontory or artificial headland. Promontories can be caused by the accelerated retreat of a cliff, or by down-drift retreat continuing at the same rate prior to construction (Brown, 2008). Examples from Overstrand, Norfolk, UK and Hornsea, Holderness, UK, which have both been defended for over a century, are shown in Figures 1 and 2. Evidence of accelerated land loss, up to $88 \pm 42 \mathrm{~m}$ after defence construction at Hornsea (in 1906 and subsequent upgrades, which potentially doubled retreat rates), is described in Brown et al. (2012a). At Overstrand, the cliffs have retreated in excess of $200 \mathrm{~m}$ since the late nineteenth century compared with the defended section.

Although there is much research into detailed defence design and construction, there has been less emphasis on how defence systems evolve, and the subsequent response of the adjacent unprotected coast. At the defences, artificial headlands progressively form and may act as barriers to sediment transport, while in between, headland bays may form. With limited practical experience and observations into how protected cliffed sites and their environs develop, there is little information readily available about why and how present coastal configurations exist and how they will evolve in the future. By understanding coastal defence evolution, coastal engineers can maximise the potential of headland-bay systems. Thus this paper will

(a) evaluate the generic historic response of constructing defences on soft cliff coastlines (in Section 2)

(b) investigate appropriate case studies, including adaptive response to ongoing coastal change (in Sections 3 and 4) 


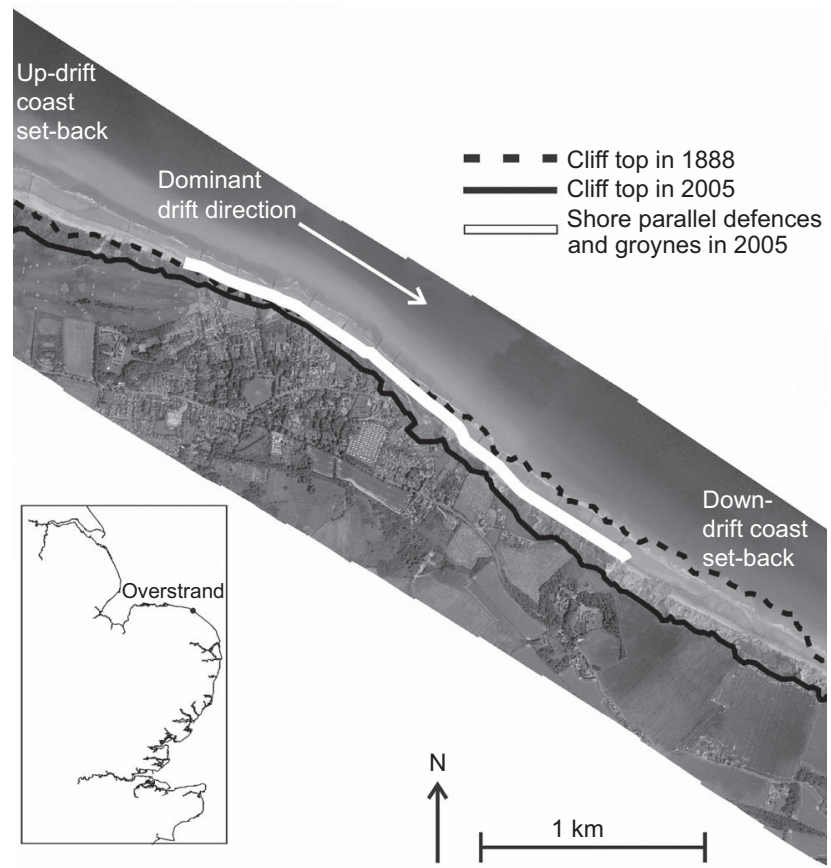

Figure 1. Continued retreat of the unprotected coast has resulted in the formation of an artificial headland at Overstrand, Norfolk where the adjacent unprotected cliffs are set-back from the protection works. Insert: Location map of Overstrand, UK. Aerial photograph courtesy of North Norfolk District Council. Map outline: (c) Crown Copyright 2013. An Ordnance Survey/EDINA supplied service

(c) discuss the past, present and future attitudes, effects, planning and engineering implications of soft cliff protection (in Section 5).

\section{History of defence construction and shoreline response}

To protect eroding coasts there are two main types of engineering structures: (a) shore parallel defences, and (b) shore perpendicular defences.

(a) Shore parallel defences (e.g. seawalls, rock armouring, baffles, ripraps, breakwaters) maintain shoreline position by limiting wave attack at the cliff base, but allow longshore drift to continue. Sediment processes may be affected in front of the wall due to wave reflection, refraction and diffraction off the wall, lowering beach levels (Silvester, 1976; Tait and Griggs, 1990).

(b) Shore perpendicular defences (e.g. harbour arms and groynes) trap sediment and allow a beach to build by inhibiting longshore drift. Up-drift of the defence, sediment accretes, but down-drift there is often a sediment deficit (Komar, 1976; Tait and Griggs, 1990).

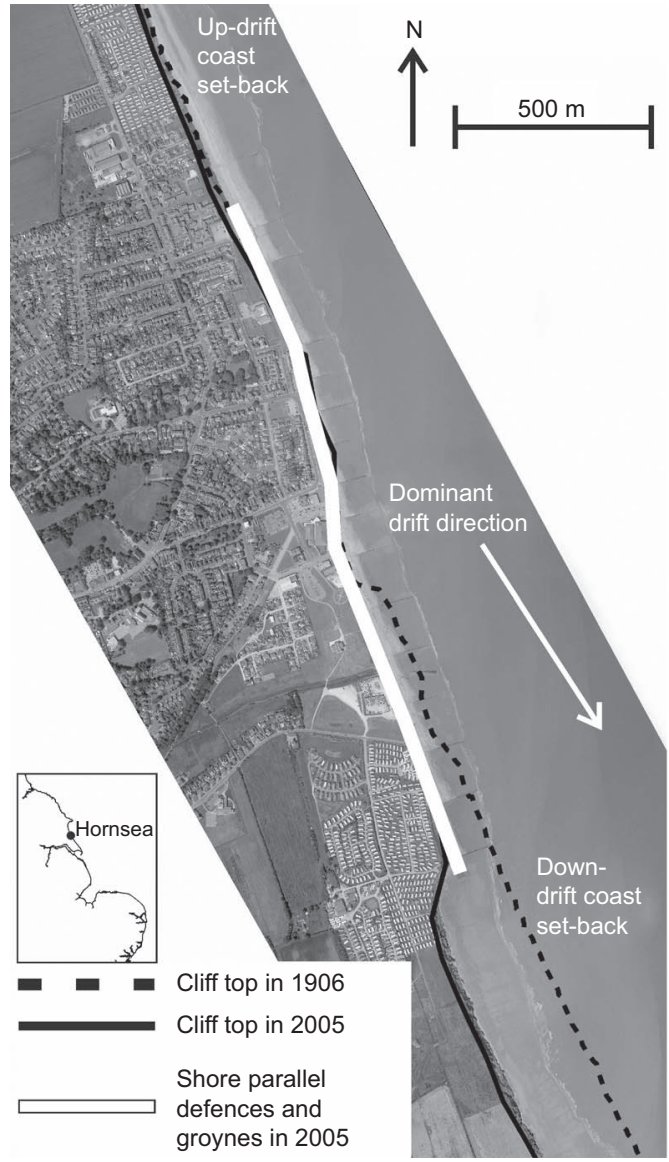

Figure 2. Continued retreat of the unprotected coast has resulted in the formation of an artificial headland at Hornsea, Holderness where the adjacent unprotected cliffs are set-back from the protection works. Insert: Location map of Hornsea. Aerial photograph courtesy of East Riding of Yorkshire District Council. Map outline (C) Crown Copyright 2013. An Ordnance Survey/EDINA supplied service

Despite shoreline defences, some recession of the cliff top is likely to continue due to subaerial and weathering processes as the cliff adopts a stable planform.

Early attempts to build groynes and seawalls to protect coastal towns in the UK had limited success, and it was not until the late nineteenth/early twentieth century that defences became more efficient (see the engineering challenges described in Topley (1885) and Ward (1922)). Such literature and Ordnance Survey map evidence from the mid-nineteenth century onwards indicates that as engineers' experience grew, they found that the most efficient way to maintain shoreline position was to build a seawall (or other shore-parallel defence), and then construct a groyne field (a shore-perpendicular defence) to encourage a beach to develop to protect the seawall, or vice 
versa. Crucially they realised that a combination of seawalls and groynes was required to hold shoreline position. Examples of a mix of defences schemes can be seen around the UK, for example at Lyme Regis or Bournemouth in Dorset.

Despite improving engineering design, nineteenth-century defences were often built with little regard for any impact they had on the adjacent coast (Topley, 1885). Frequently, constructing defences resulted in a reduction in longshore drift on the down-drift coast by way of the dual processes of reducing sediment supply from the cliff and inhibiting sediment movement, thus creating a sediment deficit. This led to lowering beach levels, localised deeper water as the unprotected coast continued to erode causing it to become set-back with respect to the defences (Griggs et al., 1990; Tait and Griggs, 1990). Set-back often occurs in a crenulate shape (Silvester and Hsu, 1997), which can potentially occur for tens to thousands of metres down-drift (Brown, 2008; Galgano, 1998; Komar, 1976; Viles and Spencer, 1995). The rate of setback is determined by the defence dimensions, type of defence, the rate and magnitude of longshore drift, the efficiency of the defence to retain sediment reducing longshore drift, wave climate and the strength and composition of the cliff material.

For shore-parallel defences, the resultant set-back is termed 'end effects', which incorporates end scour and flanking (Griggs and Tait, 1989; Griggs et al., 1990; Tait and Griggs, 1990) and for shore-perpendicular defences, the phenomenon is known as the 'terminal groyne effect' (Figure 3). Strictly the latter definition only occurs when the retreat rate of the undefended down-drift coast increases after defence construction, causing excessive land loss. In practice, however, this is not always the case (Brown, 2008), as often detailed assessments of retreat at each site where a terminal groyne effect has occurred has not been made, or the set-back happens up-drift of the defences. Historically, many engineers did not consider constructing a terminal structure to defences to overcome 'end effects' or the 'terminal groyne effect', as often the land downdrift of the defences was deemed of low economic value. Alternatively terminal structures were costed out of the design. However, as set-back problems arose, they were often added to the defence at a later date.

\section{Engineering response to building defences}

Using case study examples, set-backs adjacent to defences and engineering responses have been investigated, with many examples taken from Brown (2008) and Brown et al. (2012a, 2012b). Barton-on-Sea, Hampshire (Figure 4, and investigated in further detail in Brown et al. (2012b)) is located on soft Palaeogene unlithified sand and clay cliffs (Bristow et al., 1991), which are approximately $25 \mathrm{~m}$ high and fronted by a shingle beach. Before being defended they eroded at approximately $1 \mathrm{~m} /$ year (Brown et al., 2012b). The first major defences of drains and wooden groynes were constructed in 1964, which led to $700 \mathrm{~m}$ of cliff being protected, followed by further defences in 1967-1968, creating a length of $1800 \mathrm{~m}$ of protected shoreline. Further upgrades and extensions of the rock groynes, revetment and nourishment were undertaken.

Figure 5 illustrates the history of set-back at Barton-on-Sea where a time series of photographs from 1967 to 2005 focuses on the terminal (down-drift) groyne and shore-parallel rock armouring. The coastline without defences is shown in Figure 5(a). Soon after the initial defences of wooden groynes were constructed (no photograph available), the continued retreat of the adjacent unprotected shoreline resulted in end effects and set-backs. Set-back continued to such an extent, that defences

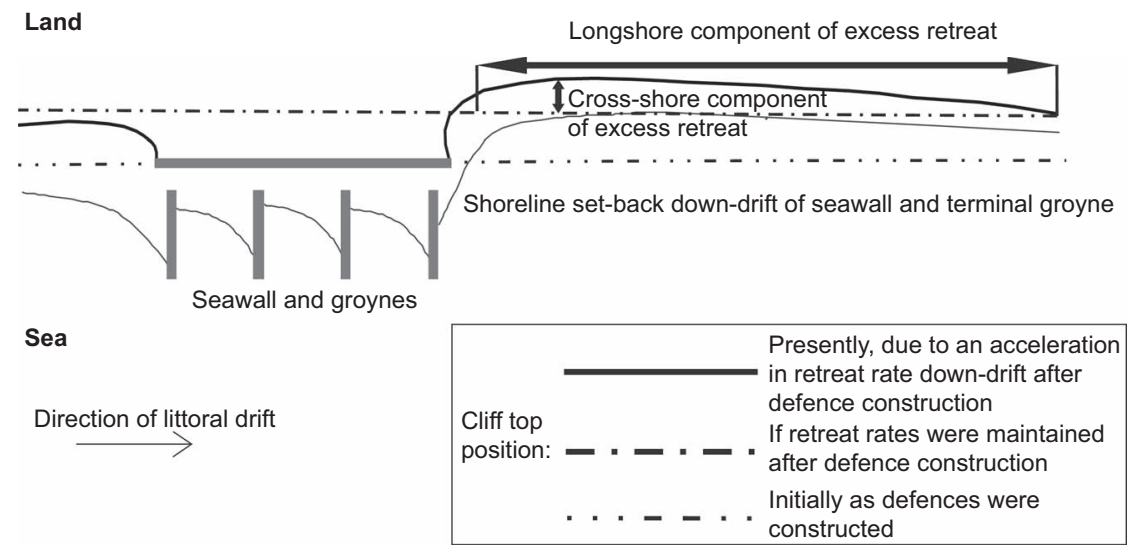

Figure 3. Down-drift response of a shoreline due to end effects and the terminal groyne effect. Set-backs can occur adjacent to the defences, even if retreat rates do not accelerate 


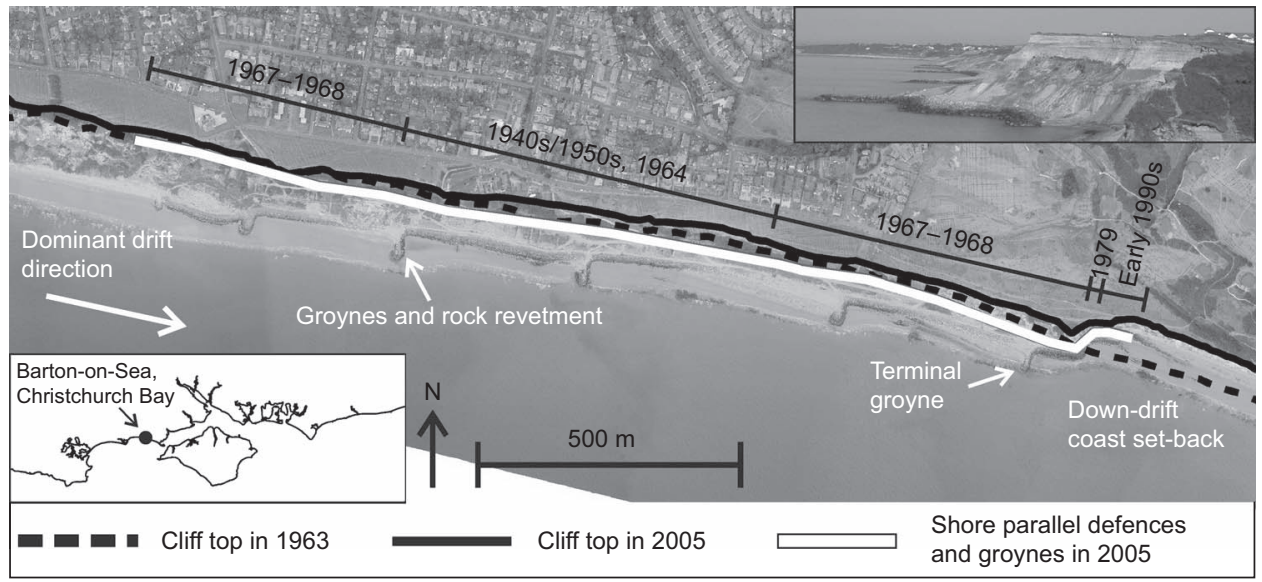

Figure 4. Defences at Barton-on-Sea, Hampshire. Dates indicate times of major defence constructions and extensions. Bottom insert: Location map of Christchurch Bay, UK. Top insert: Side-on view of the defences looking up-drift. Aerial photograph courtesy of the Channel Coastal Observatory. Map outline (c) Crown Copyright 2013. An Ordnance Survey/EDINA supplied service started to become outflanked. This sparked the engineering response of strengthening all defences, including the revetment and terminal groyne, and included $100 \mathrm{~m}$ of rock armouring (Figure 5(b)). Due to continuing set-back and outflanking, a further extension of $10 \mathrm{~m}$ of rock armouring was required in 1979 (Figure 5(c)). A further $60 \mathrm{~m}$ extension of rock armouring occurred in the early 1990s (Figure 5(d)). Between 1993 and 2005 , the continued retreat of the coast resulted in a $22 \mathrm{~m}$ setback between the defences and the cliff (Figure 5(e)).

At Barton-on-Sea, the engineering approach to overcome excessive set-back and outflanking due to end effects and the terminal groyne effect was to extend the defence parallel to the shore. This was undertaken on three occasions, and is now of a sufficient length that a significant amount of outflanking will need to occur before the defence becomes unstable. Extending defences is a common approach to overcoming set-backs and outflanking. Table 1 lists approaches at other sites worldwide where the terminal groyne effect and end effects have occurred, and their solutions to the set-back problem (Anderson et al., 1983; Dette and Gärtner, 1987; East Riding of Yorkshire Council, 2004; Granja and Carvalho, 1991, 1995; Kana et al., 2004). Other solutions include sand by-passing, semi-permeable groynes, or a series of groynes becoming progressively shorter and lower away from the defences (Galgano, 1998; Poff et al., 2004; Russell, 1960). Table 1 indicates that some approaches have been more successful than others in reducing outflanking. Such a variety of engineered response indicates that there is no universal solution to the problem. One common 'solution' is creating a shore-parallel barrier along the cliff base, at $90^{\circ}$ to the terminal groyne, although this too could be outflanked. Nevertheless, the experience at Barton-on-Sea and others sites (e.g. Hornsea, Withernsea (Brown, 2008) and Smith Point, Chesapeake Bay, Virginia
(Anderson et al., 1983)), suggests that outflanking of a shoreparallel breakwater takes a longer period of time compared with a shore-perpendicular barrier as it creates a lower energy environment between the defence and cliff for waves to dissipate.

On shorelines up-drift of defences a similar process of set-back, outflanking and defence extensions occur, albeit at a slower rate, which can also lead to headland formation. Up-drift setbacks are more likely to occur where there is another defence scheme a short distance up-drift, depleting longshore transport (e.g. up-drift of Overstrand, Norfolk which is under the influence of the defences of Cromer (Figure 1)), or where defences have been present for long time periods (e.g. Hornsea, Holderness, as shown in Figure 2 where substantial defences have been present from at least the 1890s). Factors affecting long-term cliff evolution and headland formation include wave direction, wave height, number of large storms over a period of years and geological variations in the cliff material affecting rate of retreat and sediment availability.

A study of headland formation around England and Wales (Brown, 2008) investigated the planform shape of artificial headlands, from those taking a few years to form to major defence systems evolving for over a century. It revealed that the planform of artificial headlands are primarily asymmetrically shaped (where the down-drift coast is set-back), and secondly symmetrically shaped (where the up- and down-drift coast is set-back). Symmetrical headlands (e.g. Overstrand, Norfolk (Figure 1); Cromer, Norfolk; Barmston, Holderness) occur where there have been multiple set-backs, outflanking and extensions either side of the initial defence. Asymmetrical headlands (e.g. Hornsea, Holderness (Figure 2); Reculver, Kent; Lyme Regis, Dorset) occur when a series of set-backs, 


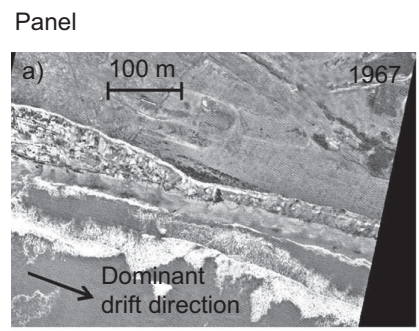

\section{History}

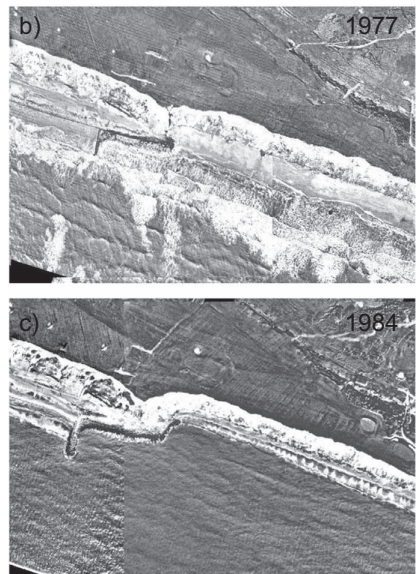

Shoreline was unprotected and formed a natural promontory, probably due to the geology. $700 \mathrm{~m}$ of defences were present $600 \mathrm{~m}$ up-drift of the promontory. In 1967-1968, 16 timber groynes and a rock-filled revetment were constructed, terminating at the promontory, making a total defence length of $1800 \mathrm{~m}$.

The terminal groyne and revetment were strengthened (but not extended) with $100 \mathrm{~m}$ of rock armouring on top of existing defences.

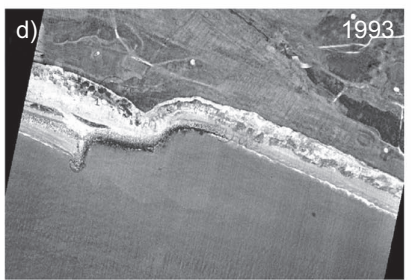

Between 1977 and 1984 the down-drift coast became set-back by $13 \mathrm{~m}$. An additional $10 \mathrm{~m}$ of shore-parallel armouring ( $\sim 0.5 \%$ of total defence length) was placed at the down-drift end of the structure along the cliff base in 1979 .

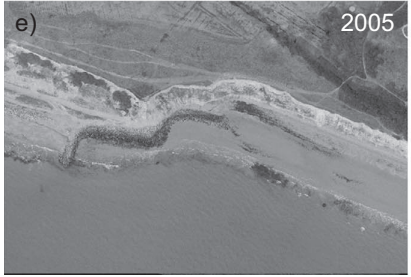

Set-back and outflanking continued down-drift and behind the extended rock armouring. This caused a further rock armour extension of $60 \mathrm{~m}$ ( $3 \%$ of total defence length) along the cliff base by 1993 , making a total length of $1870 \mathrm{~m}$ of defences.

Figure 5. Progressive extension of the terminal structure at Bartonon-Sea, Hampshire. Aerial photographs courtesy of New Forest District Council and the Channel Coastal Observatory. North is vertically upwards

outflanking and extensions is dominant on the down-drift side. These types are shown in Table 2. Symmetrical headlands are more at risk from outflanking and defence extensions than asymmetrical headlands as the set-back problem is more acute at both ends. Generally, following laws of refraction, one may expect symmetrical headlands to experience greater wave attack than asymmetrical headlands as a greater part of the defence stands seaward of the adjacent undefended coast, allowing waves to converge. Thus symmetrical headlands are more difficult, and probably more costly to defend. Symmetrical headlands can also occur near a drift divide.
Asymmetrical headlands occur when the initial, most up-drift groyne is efficient in retaining sediment up-drift of the defences, thus reducing the erosion on the adjacent coast. Typically the down-drift flank is longer than the up-drift flank. Excess retreat is more severe when longshore drift originates from one dominant direction.

\section{Management response to removing defences}

Building defences restricts sediment movement, allowing a beach to build and protect the coast (Dawson et al., 2009). On 


\begin{tabular}{|c|c|c|c|}
\hline Location and reference & Defence type & Solution to outflanking & Outcome \\
\hline $\begin{array}{l}\text { Hornsea, Holderness, } \\
\text { UK (East Riding of } \\
\text { Yorkshire Council, 2004) }\end{array}$ & Seawall and groynes & $\begin{array}{l}\text { Outflanking structure } \\
\text { (groyne and shore } \\
\text { parallel defence) not } \\
\text { connected to the main } \\
\text { defences }\end{array}$ & $\begin{array}{l}\text { Strengthening and maintenance of structure } \\
\text { required, but successful in inhibiting } \\
\text { outflanking }\end{array}$ \\
\hline $\begin{array}{l}\text { Withernsea, Holderness, } \\
\text { UK (East Riding of Yorkshire } \\
\text { Council, 2004) }\end{array}$ & Seawall and groynes & Beach breakwater & $\begin{array}{l}\text { Structure was not of the correct size, so was } \\
\text { removed and replaced by extending rock } \\
\text { armouring along cliff base }\end{array}$ \\
\hline $\begin{array}{l}\text { Sylt, Germany (Dette } \\
\text { and Gärtner, 1987) }\end{array}$ & Seawall and groynes & Seawall extended & $\begin{array}{l}\text { Continued erosion and beach lowering led to } \\
\text { toe protection and armouring and further } \\
\text { seawall extensions }\end{array}$ \\
\hline $\begin{array}{l}\text { Ofir-Apúlia, Portugal } \\
\text { (Granja and Carvalho, } \\
\text { 1991, 1995) }\end{array}$ & $\begin{array}{l}\text { Revetment and rock } \\
\text { groynes. }\end{array}$ & $\begin{array}{l}\text { Extended revetment and } \\
\text { construction of groyne } \\
\text { down-drift. }\end{array}$ & $\begin{array}{l}\text { Revetment and groyne field extended, } \\
\text { shifting the problem down-drift away from } \\
\text { cliff-top infrastructure }\end{array}$ \\
\hline $\begin{array}{l}\text { Smith Point, Virginia, USA } \\
\text { (Anderson et al., 1983) }\end{array}$ & Groynes & $\begin{array}{l}\text { Spur constructed at } 90^{\circ} \\
\text { to terminal groyne } \\
\text { pointing down-drift }\end{array}$ & $\begin{array}{l}\text { Successful in creating a lower energy } \\
\text { environment behind terminal groyne and } \\
\text { trapping sands, reducing outflanking }\end{array}$ \\
\hline $\begin{array}{l}\text { Edisto Beach, South Carolina, } \\
\text { USA (Kana et al., 2004) }\end{array}$ & Wooden groynes & $\begin{array}{l}\text { Extended groynes and } \\
\text { nourished beach }\end{array}$ & $\begin{array}{l}\text { Resulted in repeated extensions and } \\
\text { nourishments }\end{array}$ \\
\hline
\end{tabular}

Table 1. Examples of engineered responses to outflanking on eroding coasts

heavily defended coastlines, lack of sediment in one locality can make defences more vulnerable to wave attack. Thus they require greater maintenance to prevent outflanking. Where or when this cannot be undertaken, or under present management options the land falls short of the benefit-to-cost ratio required to maintain defences, one option is not to maintain defences, or partially or totally remove them.
At Happisburgh, Norfolk (Figure 6), defences were constructed in 1958 (wooden revetments) and 1968 (wooden groynes) on the soft cliff coastline which formerly eroded at approximately $1 \mathrm{~m} /$ year (Clayton, 1989). From the late 1980s, the defences were not maintained due to lack of agreement regarding coastal protection, and secondly a lack of funding (Coastal Concern Action Group, 2008). By 1991, defence
Headland platform

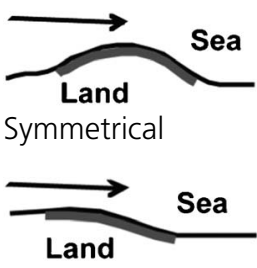

Asymmetrical

Relative shoreline position after defence construction

\begin{tabular}{|c|c|c|}
\hline Up-drift & $\begin{array}{l}\text { Defended: headland or } \\
\text { proto headland }\end{array}$ & Down-drift \\
\hline $\begin{array}{l}\text { Mimics down-drift response: } \\
\text { Multiple set-backs due to a } \\
\text { maintained retreat rate after } \\
\text { defence construction }\end{array}$ & Reduced or stopped & $\begin{array}{l}\text { Multiple set-backs due to } \\
\text { increased or maintained retreat } \\
\text { rates after defence } \\
\text { construction }\end{array}$ \\
\hline $\begin{array}{l}\text { Less set-back than down-drift, } \\
\text { with reduced retreat rates } \\
\text { after defence construction }\end{array}$ & Reduced or stopped & $\begin{array}{l}\text { Multiple set-backs due to } \\
\text { increased or maintained retreat } \\
\text { rates after defence } \\
\text { construction }\end{array}$ \\
\hline
\end{tabular}

Table 2. Formation of symmetrical and asymmetrical headlands. The arrow indicates drift direction, the black line the coastline and the bold grey line the locality of defences. Developed from Brown (2008) 


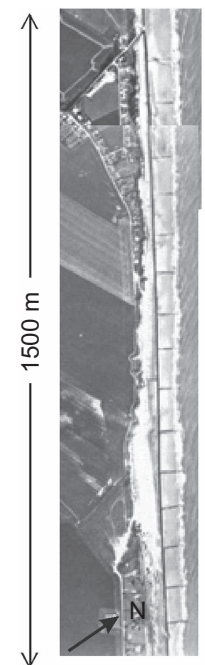

1986

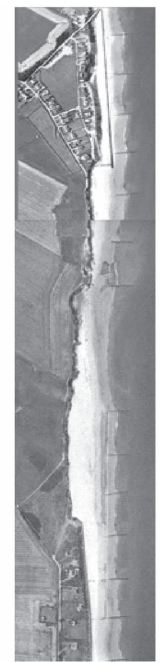

1997

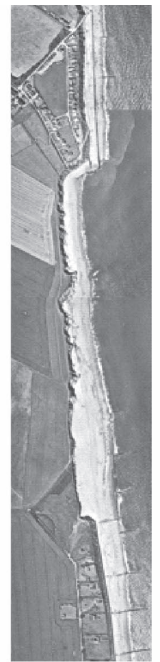

2000

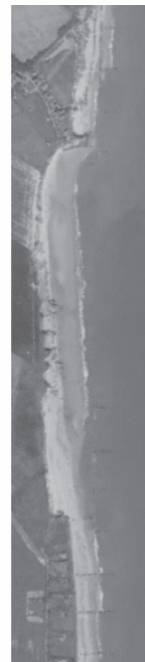

2005

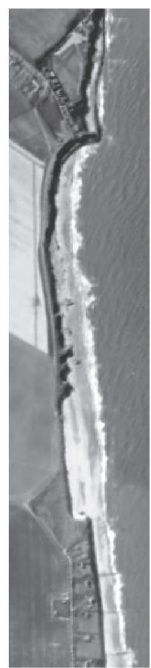

2009

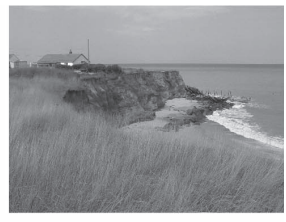

2006

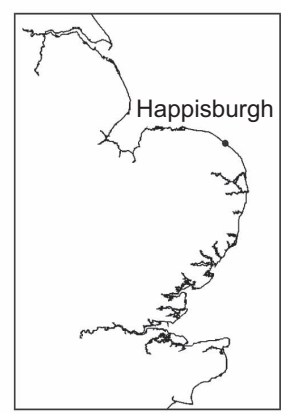

Figure 6. The development of defence abandonment and subsequent retreat at Happisburgh, Norfolk. Dominant drift is from north-west to south-east. Aerial photographs courtesy of North

Norfolk District Council (1986-2005) and (C) Google Earth (2009). Map outline (c) Crown Copyright 2013. An Ordnance Survey/EDINA supplied service failure led to selective defence removal on safety grounds along $900 \mathrm{~m}$ of coast (HR Wallingford, 2001), while adjacent defences remained. Subsequently, where defences were removed, excessive retreat occurred so that over a period of 14 years, the cliff eroded on average $100 \mathrm{~m}$ landward, creating an embayment (Brown, 2008). Between September 2001 and September 2003, $36000 \mathrm{t}$ of sediment were eroded from a $100 \mathrm{~m}$ section of cliff (Poulton et al., 2006), with retreat rates between 8 and $10 \mathrm{~m} / \mathrm{year}$ being recorded. Much of this sediment has helped slow subsequent erosion. In 2007, with financial help from the local authority, the local community helped fund rock armouring along the cliff base to slow erosion (Frew, 2012). This has helped to buy time for the community to accept coastal change and debate the long-term management options available. The adjacent coasts which remain defended protrude, forming artificial headlands. The local authority is continuing to work with the residents of Happisburgh to further integrate coastal change within the community (Frew, 2012).

\section{Discussion}

Through case study examples, this research has investigated the creation of end effects and the terminal groyne effect, and potential solutions to the continued set-back of the coast which can lead to the formation of headlands. With a high reliance and investment on coastal defences to protect from land loss, understanding past processes of coastal change is important for long-term future coastal evolution and to strategically plan for the optimum management options in a cost-effective and sustainable way.
When early (eighteenth century) defences were constructed, and even up to more recent decades, there was often a lack of concern or awareness of the problems associated with end effects and the terminal groyne effect. This resulted in problems on the adjacent coast such as excessive land loss. The results presented in Section 3 (including the Barton-on-Sea case study in Figure 5 and the examples listed in Table 1), as well as other case study areas (see Brown (2008)) indicate that building defences leads to outflanking, set-back, and defence extensions, thus potentially initiating cycles of defence construction, upgrade and extension. Figure 7 illustrates the connections between the building of defences and subsequent outflanking, abandonment, bay growth and headland formation. The upper part of the figure represents building defences, leading to coastal management decisions, and the lower part of the figure relates to defence abandonment. Predictions of the shape and rate of retreat (to anticipate land and infrastructure loss) are required for shoreline planning and management, and these are related to the defences and how the set-back is caused.

The engineering, planning and management implications from the case studies and the actions presented in Figure 7 fall into three categories of the past, present and future evolution of the coast, and the engineer's response to coastal change.

\subsection{Past response}

In past decades there was limited consideration of the effects of defences on the adjacent coast, including set-backs and the longterm evolution and strategic management. Defences were often constructed up to a local authority boundary creating a series of 


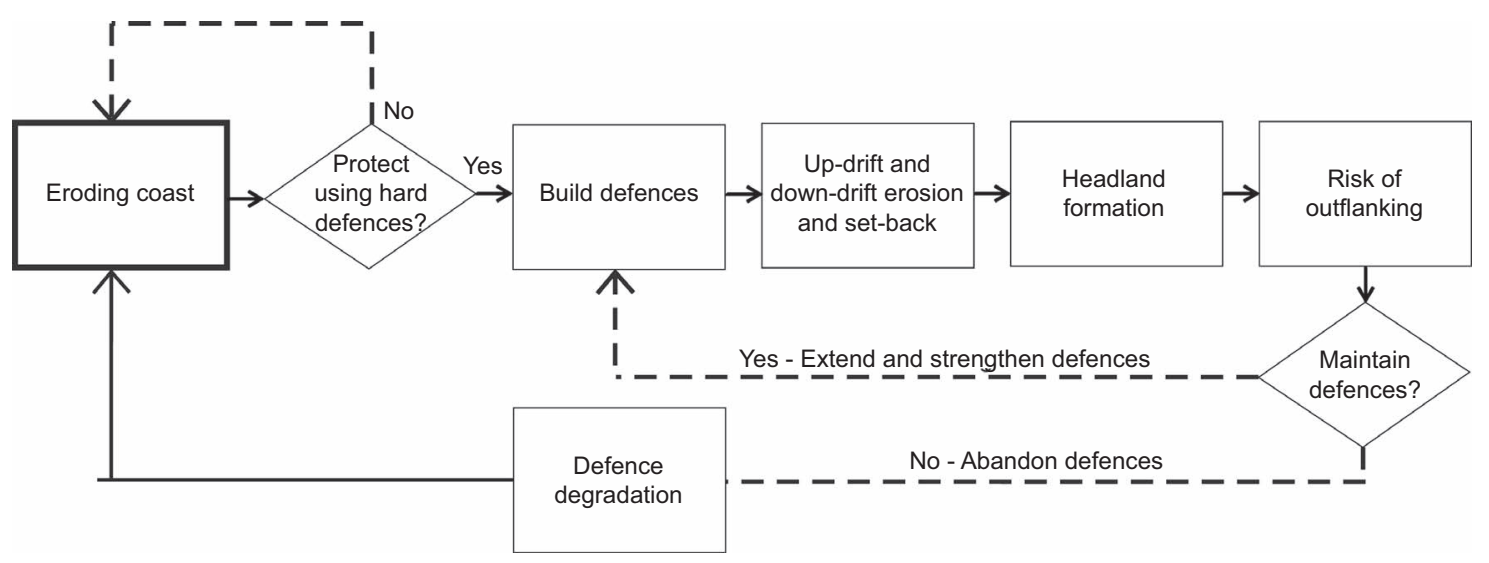

Figure 7. The development of outflanking and headland formation due to protection on an eroding cliffed coastline

set-backs on the adjacent coast (e.g the Dorset/Hampshire boundary, Blackpool/Lytham St Annes), often resulting in end effects or the terminal groyne effect. A common approach to overcome set-back was, where possible, to extend defences. However, this was only a short term solution as the problem of increased erosion was moved down-drift (Silvester and Hsu, 1997). Defences have contributed to shoreline steepening (Taylor et al., 2004) leading to deeper water, increased wave attack and the outflanking of the protection. Subsequently along UK softcliffed coasts this has resulted in the formation of a number of artificial headlands which require additional or stronger protection than when they were first constructed (Brown and Barton, 2007; Valentin, 1954). Evidence can be found through historical literature, old photographs and maps. For instance at Withernsea, Holderness, a seawall was constructed north of the pier in the late nineteenth century. Not sufficient to hold a beach, groynes were added after World War 2. As the coast changed and defences became aged, the sea wall was replaced and most probably upgraded. Finally, in the late twentieth century armouring was placed at the base of the seawall to reduce the possibility of scour from wave attack (Brown, 2008). Historical photographic evidence of the seawall from 1912 (Whittaker, 1990) suggests that beach levels have lowered relative to a century ago. Additionally, adjacent defences and the promenade at Withernsea were also strengthened and extended as the unprotected coast continued to erode, threatening to outflank defences. This was probably partly due to increased leisure time spent at the coast. Similar evidence can be found for other defended English towns and villages, suggesting strengthening and extension was common practice (Brown, 2008).

\subsection{Present response}

Shoreline management plans, introduced in 1995 covering the $6000 \mathrm{~km}$ coastline of England and Wales (Cooper et al., 2002;
Defra, 2006; Leafe et al., 1998) aimed to integrate strategic shoreline planning over a time scale of 100 years. Natural boundaries were considered rather than administrative ones, known as coastal management cells (Leafe et al., 1998). With changing planning and management regulations, funding became more challenging to obtain where there was a low benefit-to-cost ratio.

In recent decades, new protection schemes have taken greater account of end effects and terminal groyne effects through modelling of the defences (e.g. Sea Palling, Norfolk (Hamer et al., 1998)). Novel approaches to solving the set-back problem are to be commended (for example, an offshore breakwater was constructed at the down-drift end of the defences at Withernsea, Holderness), although further research is necessary until a generic 'solution' is found to overcome the problem. Improved monitoring and maintenance of the coast has led to a more anticipatory approach to coastal change, such as the Channel Coastal Observatory (www.channelcoast. org), which hosts the English strategic coastal monitoring programme where regular coastal monitoring is undertaken. In response to decision making and coherent monitoring, the programme has been expanded in recent years.

A new form of set-back has also been created through the process of defence abandonment, represented in the lower half of Figure 7, and as demonstrated through the case study of Happisburgh (Section 4). Removing the defences allows greater sediment release from the cliff, offering a natural form of protection. Happisburgh is a dramatic example of how changes to policy have changed the shape of the coastline. Following this, national policies are shifting from 'defended and protect' to 'risk management', working with natural processes (Environment Agency, 2010). These include taking a 
holistic review of problems, with greater consideration given to coastal management at different temporal and spatial scales, acknowledging uncertainties and developing more sustainable management policies (Pontee and Parsons, 2010). Simultaneously to Happisburgh's plight, other localities were not able to apply for government funds to protect properties, so used their own innovative approaches to reduce erosion risk, such as at Ulrome, Holderness (seawall), and Easton Bavents, Suffolk (unwanted clay and soil placed on beach). The communities of Happisburgh and others have demonstrated a need for individuals, communities and businesses to respond to coastal change, in particular funding opportunities and potential abandonment through greater stakeholder engagement. One vehicle to achieving this has been the UK Department for Food and Rural Affairs (Defra)-funded coastal change pathfinder programmes (including North Norfolk and Happisburgh (Frew, 2012)), which are aimed at engaging communities to plan and innovatively adapt for coastal change at a local level. Engaging, educating and allowing stakeholders to envisage change, helps to increase awareness and responsibility for their environment. Helping this are alternative methods of funding, moving away from central government to partnership funding, where local businesses and organisations have the opportunity to financially support schemes. The benefits indicate greater adaptive responses to suit local needs, increased responsibility and the long-term management of risk in order to maintain the environment, allowing communities to thrive into the future (Environment Agency, 2012).

\subsection{Future response}

Response to erosion and flooding is becoming more integrated so that values of co-ordination, strategic risk management and good social and environmental governance are defined with a systems approach (e.g. sediment cell analysis), but also set in broader levels of planning and legislation (e.g from international EU directives to local planning decisions) to achieve a more sustainable coastal policy, with greater benefits for all (Defra, 2009).

While numerous managed realignment schemes have undertaken planned defence removal on low-lying sites (see ABP Marine Environmental Research, 2012), Happisburgh, Norfolk is the only significant cliffed site known to the authors where defence removal of shore-parallel and shoreperpendicular structures (having been in place for several decades) has been undertaken in recent decades in the UK. With the second round of shoreline management plans advocating planned defence removal on cliffed sites, engineers will need to consider how this process will be undertaken. For instance, the shoreline management plan for parts of Norfolk and Suffolk (Kelling to Lowestoft Ness Shoreline Management Plan, 2010) recommends large parts of the coast should be realigned over this century. In the medium term, the coast will be in transition as abandonment takes place and potentially many new end effects and set-backs will emerge. Over the long term only selective defences remain (mostly around the main towns and villages and essential infrastructure) so there will be fewer defended coast/eroding coast discontinuities compared with the medium, or even short term, meaning that the number of set-backs will be reduced.

Future coastal cliffed response to abandonment will depend on how, where and when the coastal defences fail. When constructing defences, groynes should be built from downdrift to up-drift to minimise the excess retreat on the downdrift coast (Galgano, 2004). Hence it can be argued that defences should be abandoned from the up-drift to the downdrift direction, releasing beneficial sediment which would be provided for the down-drift coast, thus reducing the short-term impact of the accelerated retreat. Although this may be beneficial in the long term, others (e.g. Dickson et al. (2007)) propose that defences should first be abandoned in areas of low land value following shoreline management plan recommendations. Ideally a mix of these approaches is required, creating a balance between loss of valuable land, sediment availability and sufficient time for engineers and scientists to gain experience and understanding to improve predictions of coastal response and defence removal. As such, national policy can sometimes be difficult to translate at a local level (Few et al., 2007). For instance, some shoreline management plans fail to provide insight into which defences will fail first and how engineers will manage the shoreline on a very practical level; engineers may have considered this, but it is not necessarily detailed within the plan, and only in recent years is this emerging (e.g. Pontee and Parsons (2010)). The aesthetics of removing defences have not been fully considered; those visiting the coast may choose to go places that remain defended or have never been defended, rather than those localities where infrastructure is actively being lost to the sea. Thus those communities will potentially lose a source of income. Safety issues may arise through old defences, causing contamination (Pontee and Parsons, 2010), or from defences which have not been fully removed and may still be protruding, which could potentially injure people and prompt claims of litigation (Brown, 2008; Pontee and Parsons, 2010).

The remaining defended coast will continue to develop artificial headlands at their boundaries and lead to shoreline steepening (Taylor et al., 2004) and greater wave attack, already noted at some defended towns, for example Cromer and Overstrand in Norfolk (Craig Smith, 1973; Ward, 1922). Climate change and sea-level rise will worsen the situation. Appropriate engineering approaches (such as those listed in Table 1) into up-drift and down-drift defence terminations of new and existing headlands need to be sought, and lessons 
learnt from past practices, otherwise the defence erosion cycle (Figure 7) will be reinitiated. The emergence of a smaller number of larger headlands on eroding coasts could potentially alter sediment movement and affect retreat. As headlands protrude seaward, they will become more difficult and costly to defend. Long-term management and maintenance of the natural and artificial coastal zone is required (such as beach monitoring), so that changes to coastal processes are anticipated and defences remain efficient, thereby reducing valuable land loss.

This study has focused on UK soft cliff coasts and hard defences. Differing rates of retreat, types and number of defences, plus varying morphological conditions are all physical factors determining cliff response. It is likely that similar principles apply to low-lying land, and coasts in other countries. Soft defences, such as nourishment provides an alternative option, and can augment hard measures to reduce erosion. Adaptation response needs to be seen in a broader context of shoreline management, consulting with local needs, furthering the understanding of the interconnections between the physical coastal systems and human use to achieve a longterm vision of coastal management. UK pathfinder projects have increased public awareness into the issues surrounding long-term coastal management, creating a stronger coastal community. Partnership funding offers new opportunities and lessons must be learned concerning how to achieve the maximum benefit not just to the immediate community, but the wider environment. Furthermore, long-term budgets and the need for clearer policies present challenges (Pontee and Parsons, 2010) and require further consideration. The success of government schemes indicates continued community awareness in the coastal environmental should be encouraged.

\section{Conclusions}

Constructing groynes and seawalls on an eroding soft cliff coast results in set-back of the adjacent undefended coast known as 'end effects' or the 'terminal groyne effect'. This is most extreme down-drift of the defence as there is often a sediment deficit. Although a widely recognised problem, it has frequently been ignored in the design of the defence. Without engineering intervention, continued retreat of the unprotected hinterland leads to outflanking of the defences. Often a solution has been to strengthen and extend the defences, creating a new set-back. Thus, a cycle of defence construction, set-back, outflanking and defence extension has occurred. Extending defences on multiple occasions together with continued erosion of the adjacent coast leads to artificial headland formation.

Understanding cycles of defence extensions and subsequent set-back helps coastal engineers and planners anticipate coastal changes, including the likely need for ongoing maintenance.
Over the next few decades, the nature of set-backs will change as shoreline management plans advocate defence abandonment. Greater consideration is required by engineers and planners into how defence abandonment is undertaken practically, and the knock-on physical and human impacts. For example this could be achieved for the former through numerical modelling, or for the latter by community engagement. Over the longer term, artificial headlands will probably be less common on UK coasts as fewer towns will be defended, but they will be more pronounced as the adjacent coast will have experienced set-back for a longer time period than at present. In the long term, engineers need to consider how long artificial headlands can be defended, as the protective works will require strengthening, continued maintenance and terminal structures to reduce outflanking risk.

\section{Acknowledgements}

The lead author is grateful for the receipt of an Engineering and Physical Sciences Research Council (EPSRC) funded studentship during the course of this research. The authors are grateful to the local authorities (East Riding of Yorkshire Council, New Forest District Council, North Norfolk District Council) and their engineers, and the Channel Coastal Observatory, Southampton (www.channelcoast.org) for permission to use their aerial photographs and other data in this publication. Additional aerial imagery courtesy of Google Earth and map outlines from Crown Copyright, Ordnance Survey/EDINA 2013: http://edina.ac.uk/digimap.

\section{REFERENCES}

ABP Marine Environmental Research (2012) Online Managed Realignment Guide. See http://www.abpmer.net/omreg/ (accessed 17/01/2013).

Anderson GL, Hardaway CS and Gunn JR (1983) Beach response to spurs and groins. In Proceedings of Coastal Structures '83 (Weggel JR (ed.)). ASCE, Reston, VA, USA, pp. 727739.

Bristow CR, Freshney EC and Penn IE (1991) Geology of the Country around Bournemouth Memoir for 1:50 000 Geological Sheet 329 (England and Wales). HMSO, London, UK.

Brown S (2008) Soft Cliff Retreat Adjacent to Coastal Defences, with Particular Reference to Holderness and Christchurch Bay, UK. PhD thesis, University of Southampton, Southampton, UK.

Brown S and Barton ME (2007) Downdrift erosion and the frequency of coastal landsliding. In Landslides and Climate Change - Challenges and Solutions (McInnes R, Jakeways J, Fairbank H and Mathie E (eds)). Taylor and Francis, London, UK, pp. 429-434.

Brown S, Barton ME and Nicholls RJ (2012a) The effect of coastal defences on cliff top retreat along the Holderness coastline. Proceedings of the Yorkshire Geological Society 59(1):1-13. 
Brown S, Barton ME and Nicholls RJ (2012b) Human interference on soft cliff retreat: examples from Christchurch Bay, UK. Quarterly Journal of Engineering Geology and Hydrology 45(4): 395-404.

Clayton KM (1989) Sediment input from the Norfolk Cliffs, Eastern England - A century of coastal protection and its effect. Journal of Coastal Research 5(3): 433-442.

Coastal Concern Action Group (2008) Timeline. See http://www. happisburgh.org.uk/campaign/timeline (accessed 17/01/2013).

Cooper NJ, Barber C, Bray MJ and Carter DJ (2002) Shoreline management plans: a national review and engineering perspective. Water and Maritime Engineering 154(3): 221228.

Craig Smith SJ (1973) The Role of Wind Waves and Tidal Currents on the Evolution of Part of the East Anglian Coast. $\mathrm{PhD}$ thesis, University of East Anglia, Norfolk, UK.

Dawson RJ, Dickson M, Nicholls RJ et al. (2009) Integrated analysis of risks of coastal flooding and cliff erosion under scenarios of long term change. Climatic Change 95(1-2): 249-288.

Defra (2006) Shoreline Management Plan Guidance. Volume 1: Aims and Guidance. Defra, London, UK. See http://www. defra.gov.uk/publications/files/pb11726-smpg-vol1-060308. pdf (accessed 17/01/2013).

Defra (2009) Appraisal of Flood and Coastal Risk Management. A Defra Policy Statement. Defra, London, UK. See http:// www.defra.gov.uk/publications/files/pb13278-erosionmanage-090619.pdf (accessed 17/01/2013).

Dette HH and Gärtner J (1987) Time history of a seawall on the island of Sylt. In Coastal Sediments ' 87 (Kraus NC (ed.)). ASCE, New York, USA, pp. 1006-1022.

Dickson ME, Walkden MJA and Hall JW (2007) Systemic impacts of climate change on an eroding coastal region over the twenty-first century. Climatic Change 84: 141-166.

East Riding of Yorkshire Council (2004) Coastal Information Pack East Riding of Yorkshire's Coastline Flamborough Head to Spurn Point. See http://www.eastriding.gov.uk/ coastalexplorer/documents.html (accessed 17/01/2013).

Environment Agency (2010) Flood and Coastal Erosion Risk Management Appraisal Guidance. Environment Agency, Bristol, UK. See http://a0768b4a8a31e106d8b050dc802554eb38a24458b98ff72d550b.r19.cf3.rackcdn.com/ geho0310bsdb-e-e.pdf (accessed 17/01/2013).

Environment Agency (2012) Principles for Implementing Flood and Coastal Resilience Funding Partnerships. Environment Agency, Bristol, UK. See http://a0768b4a8a31e106d8b050dc802554eb38a24458b98ff72d550b.r19.cf3.rackcdn.com/ LIT_6696_f143f7.pdf (accessed 17/01/2013).

Eurosion (2004) Living with Coastal Erosion in Europe: Sediment and Space for Sustainability Part II - Maps and Statistics. See http://www.eurosion.org/reports-online/part2.pdf (accessed 17/01/2013).
Few R, Brown K and Tompkins EL (2007) Climate change and coastal management decisions: insights from Christchurch Bay, UK. Coastal Management 35(2-3): 255-270.

Frew P (2012) Adapting to coastal change in north Norfolk, UK. Proceedings of Institution of Civil Engineering Maritime Engineering, 165(3): 131-138, http://dx.doi.org/ 10.1680/maen.2011.23.

Galgano FA (1998) Geomorphic Analysis of Modes of Shoreline Behavior and the Influence of Tidal Inlets on Coastal Configuration. PhD thesis, University of Maryland, MD, USA.

Galgano FA (2004) Long-term effectiveness of a groin and beach fill system: A case study using shoreline change maps. Journal of Coastal Research S.I.33: 3-18.

Granja HM and Carvalho GSD (1991) The impact of 'protection' structures on the Ofir-Apúlia coastal zone (NW Portugal). Quaternary International 9: 81-85.

Granja HM and Carvalho GSD (1995) Is the coastline "protections" of Portugal by hard engineering structures effective? Journal of Coastal Research 11(4): 1229-1241.

Griggs GB and Tait JF (1989) Observations of the end effects of seawalls. Shore and Beach 57(1): 25-26.

Griggs GB, Tait JF and Scott K (1990) The impacts of shoreline protection structures on beachs along Monterey Bay, California. In Coastal Engineering (Edge BL (ed.)). ASCE, New York, USA, pp. 2810-2823.

Hamer BA, Hayman SJ, Elsdeon PA and Fleming AA (1998) Happisburgh to Winterton sea defences: Stage 2. In Coastlines, Structures and Breakwaters (Allsop NWH (ed.)). Thomas Telford, London, UK, pp. 119-134.

HR Wallingford (2001) Ostend to Cart Gap Coastal Strategy Study. Executive Summary. Report EX 4342. HR Wallingford, Wallingford, UK. See http://www. northnorfolk.org/coastal/microsite/documents/Coastal_ Environment_010.pdf (accessed 17/01/2013).

Jones DKC and Lee EM (1994) Landsliding in Great Britain. HMSO, London, UK.

Kana TW, White TE and McKee PA (2004) Management and engineering guidelines for groin rehabilitation. Journal of Coastal Research S.I.33: 57-82.

Kelling to Lowestoft Ness Shoreline Management Plan (2010) Kelling to Lowestoft Ness Shoreline Management Plan First Review, Final Report, November 2010. AECOM, Cheshire, UK. See http://www.northnorfolk.org/files/SEA/SMP.zip (accessed 17/01/2013).

Komar PD (1976) Beach Processes and Sedimentation. PrenticeHall, Englewood Cliffs, NJ, USA.

Leafe R, Pethick J and Townend I (1998) Realizing the benefits of shoreline management. The Geographical Journal 164(3): 282-290.

Lee EM and Clark AR (2002) Investigation and Management of Soft Rock Cliffs. Thomas Telford, London, UK. 
Poff MT, Stephen MF, Dean RG and Mulcahy S (2004)

Permeable wood groins: Case study of their impact on the coastal system. Journal of Coastal Research S.I.33: 131144.

Pontee NI and Parsons A (2010) A review of coastal risk management in the UK. Proceedings of the Institution of Civil Engineers - Maritime Engineering 163(1): 31-42, http://dx.doi.org/10.1680/maen.2010.163.1.31.

Poulton CVL, Lee JR, Jones LD et al. (2006) Preliminary investigation into monitoring coastal erosion using terrestrial laser scanning: case study at Happisburgh, Norfolk, UK. Bulletin of the Geological Society of Norfolk 56: $45-65$.

Russell RCH (1960) Hydraulics Research Paper No 3 Coast Erosion and Defence. Nine Questions and Answers. Her Majesty's Stationery Office, London, UK.

Silvester R and Hsu JRC (1997) Coastal Stabilization. World Scientific Publishing Co Pte Ltd., Singapore.

Silvester R (1976) Headland defence of coasts. In Proceedings of the Fifteenth Coastal Engineering Conference. ACSE, New York, USA, pp. 1394-1406.
Tait JF and Griggs GB (1990) Beach response to the presence of a seawall - a comparison of field observations. Shore and Beach 58(2): 11-28.

Taylor JA, Murdock AP and Pontee NI (2004) A macroscale analysis of coastal steepening around the coast of England and Wales. Geographical Journal 170(3): 179-188.

Topley W (ed.) (1885) Rate of erosion of the sea-coasts of England and Wales and the influence of artificial abstraction of shingle or other material in that action. Report of the British Association for the Advancement of Science 1885: 404-407.

Valentin H (1954) (reprinted in 1971) Land loss at Holderness. In Applied Coastal Geomorphology (Steers JA (ed.)). Macmillan, London, UK, pp. 116-137.

Viles H and Spencer T (1995) Coastal Problems: Geomorphology, Ecology and Society at the Coast. Edward Arnold, London, UK.

Ward EM (1922) English Coastal Evolution. Methuen and Co Ltd., London, UK.

Whittaker J (1990) Old Withernsea and Surrounding Villages Remembered. Hutton Press Limited, Beverley, UK.

\section{WHAT DO YOU THINK?}

To discuss this paper, please email up to 500 words to the editor at journals@ice.org.uk. Your contribution will be forwarded to the author(s) for a reply and, if considered appropriate by the editorial panel, will be published as discussion in a future issue of the journal.

Proceedings journals rely entirely on contributions sent in by civil engineering professionals, academics and students. Papers should be 2000-5000 words long (briefing papers should be $1000-2000$ words long), with adequate illustrations and references. You can submit your paper online via www.icevirtuallibrary.com/content/journals, where you will also find detailed author guidelines. 